\begin{tabular}{|c|c|}
\hline 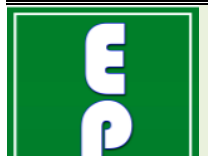 & $\begin{array}{c}\text { International Journal of Current Research } \\
\text { and Academic Review }\end{array}$ \\
\hline $\begin{array}{l}\text { EXCELLENT } \\
\text { PUBLLSHERS }\end{array}$ & $\begin{array}{c}\text { ISSN: 2347-3215 (Online) Volume } 6 \text { Number } 4 \text { (April-2018) } \\
\text { Journal homepage: http://www.ijcrar.com }\end{array}$ \\
\hline
\end{tabular}

doi: https://doi.org/10.20546/ijcrar.2018.604.003

\title{
Comparison of Exclusive and Non Exclusive Breast Feeding with the Incidence of Allergic Rhinitis in Children
}

\author{
Mulya Safri ${ }^{*}$, Muhammad Dipi Abdillah ${ }^{2}$, Aulia Rahman Putra ${ }^{3}$, Benny Kurnia ${ }^{4}$ and Muhsin ${ }^{2}$ \\ ${ }^{I}$ Department of Child Health Syiah Kuala University, Dr. Zainoel Abidin Hospital, Banda Aceh, Indonesia \\ ${ }^{2}$ Faculty of Medicine, Syiah Kuala University, Banda Aceh, Indonesia \\ ${ }^{3}$ Dr. Zainoel Abidin Hospital, Banda Aceh, Indonesia \\ ${ }^{4}$ Department of Head Neck Surgery Syiah Kuala University, Dr. Zainoel Abidin Hospital, Banda Aceh, Indonesia \\ *Corresponding author
}

\section{Abstract}

Allergic rhinitis is common chronic disease in children and the incidence increases in children aged over 5 years. Exclusive breastfeeding may reduce the risk of allergic rhinitis due to its antiallergen and anti-inflammatory properties. This study aimed to find the difference between children who were exclusively breastfed and did not exclusively breastfed to the incidence of allergic rhinitis in children. This analytic comparative with cross sectional study was conducted in Dr. Zainoel Abidin Hospital, Banda Aceh. Data collected from medical records and questionnaires completed by parents. A total of 35 children aged 5 to 18 years were collected using accidental sampling. The results shown $20(57.1 \%)$ children had a history of exclusive breastfeeding and $15(42.9 \%)$ children had a history of non-exclusive breastfeeding. About 22 $(62.9 \%)$ children suffering from intermittent allergic rhinitis, while other 13 (37.1\%) children suffering persistent allergic rhinitis. Fisher's exact test results shown statistically significant difference between Exclusive breastfeeding and non-exclusive breastfeeding to the incidence of allergic rhinitis in children aged 5 to 18 years $(P=0.005$; OR $6.995 \%$ CI $1.78-26.85)$. In conclusion, children with a history of exclusive breastfeeding had a lower frequency of allergic rhinitis symptoms. It is suggested that children with a moderate or high risk of allergy to be given exclusive breast feeding in the first 6 months of life to reduce the incidence of allergic rhinitis in the future.
\end{abstract}

\section{Article Info}

Accepted: 07 March 2017

Available Online: 20 April 2018

\section{Keywords \\ Allergic rhinitis, \\ Exclusive breast feeding, \\ Children aged $5-18$ years}

\section{Introduction}

Allergic rhinitis is a chronic upper airway disease induced by allergen exposure and produces an inflammatory process mediated by IgE with symptoms of rhinorrhea, sneezing, nasal congestion, and/or itching of the nose or eye (Tharpe and Kemp, 2015; Mims 2012). Allergic Rhinitis and its Impact on Asthma (ARIA), in collaboration with World Health Organization (WHO), states that allergic rhinitis represents a global health problem affecting around 10 to $20 \%$ of the population and this number continues year to year (Broek et al., 2010). The results of the International Study of Asthma and Allergies in Childhood (ISAAC) surveys shown the prevalence of allergic rhinitis varies worldwide. Prevalence in Southeast Asia around 5.5\% to 44.2\% 
(Tong and Lin, 2015). Allergic rhinitis is not common in children under 2 years of age, since exposure to allergens usually takes several years to develop (Tharpe and Kemp, 2015). Research conducted by ISAAC shown genetic (family history of allergy), age of child, gender, frequent airway infections, antibiotics in the first year of life, have pets, breastfeeding, socioeconomic status and the process of cesarean delivery are common risk factor for allergic rhinitis (Ji et al., 2016; Li et al., 2015).

Allergic rhinitis disease should be prevented as early as possible.Giving exclusive breastfeeding in the first 6 months of life should be a preventive factors against allergic rhinitis. (Wuryanti and Wibowo, 2015; Friedman et al., 2005; Adkinson, 2008). Previous study shown that children who did not receive exclusive breastfeeding has a prevalence of allergic rhinitis $12.4 \%$ higher than children who consumed exclusive breastfeeding (Ehlayel et al., 2008).

\section{Materials and Methods}

This analytic comparative with cross-sectional study was conducted in Dr. Zainoel Abidin HospitalBanda Aceh, the capital of Aceh Provence, from September to December 2017. A total of 45 children aged 5 to 18 years were collected by accidental sampling. Children with a history ofbreastfeeding during infancy (aged 0 to 6 months) were included into inclusion criteria. Children suffering from infections and congenital problemwere excluded in this study. Children had been diagnosed by an allergy and immunology specialist, based on examination and previous history of allergy and then divided into intermittent allergic rhinitis and persistent allergic rhinitis. Data collected from examinations, questionnaires completed by parents andmedical records. Fisher's exact test were performed to analyze the obtained data. Data collected included age, sex, history of breastfeeding, and history of previous treatment. All analyses were performed with SPSS ver. 22.0 (IBM SPSS Statistics for Windows, Ver 22.0. Armonk, NY, USA). Test results revealed statistically significant if $P$ value of $<0.05$.

\section{Results and Discussion}

We obtained 45 children that fulfilled the inclusion criteria. Subject characteristics are shown in Table 1.Most of the subject aged between 5 to 11 years old (64.4\%). In intermittent allergic rhinitis group, $81.2 \%$ of subjects feel slightly interrupted in performing daily activities, but in persistent allergic rhinitis group, $87.5 \%$ of subjects feel very interrupted in performing daily activities. Exclusive breastfeeding during infancy (0 to 6 months) were given into $81.5 \%$ subjects in intermittent allergic rhinitis group. And in persistent allergic rhinitis group, $61.1 \%$ of subjects were given non exclusive breastfeeding during infancy. About $71.1 \%$ of subjects were grouped into low-moderate risk allergy.

Subject in intermittent allergic rhinitis group have slightly different numbers than in persistent allergic rhinitis group, $29(64.4 \%)$ vs $16(35.6 \%)$, respectively (Figure 1). $27(60 \%)$ of total subjects were given exclusive breastfeeding during infancy (0 to 6 months) (Figure 2).

We analyzed the relation between variables in Table 2 using Fisher's exact test because chi-square test is not suitable. The result showed a statistically significant difference between allergic rhinitis and feeding history in infancy $(P=0.005)$. We also conducted a MaentelHaenszel analysis to find the risk of allergic rhinitis on a history of breastfeeding. We found that children who consumed non exclusive breastfeeding will have 6.9 times higher to suffer persistent allergic rhinitis $(95 \% \mathrm{CI}$ 1.78-26.85).

Allergic rhinitis disease should be prevented as early as possible because this problem will inhibit the growth and development process of children (Wuryanti and Wibowo, 2015). Giving exclusive breast feeding should be a preventive factors against allergic rhinitis. This type of milk contains Transforming growth factor (TGF- $\beta$ ), CD14 , lactoferrin, and IgA which plays an important role in the prevention of allergen exposure and the development of allergies in children.TGF- $\beta$ improving the individual ability for producing inner IgA against substances that can trigger allergy as $\beta$-lactoglobulin, casein, gliadin, and ovalbumin that are normally on food or drinks.TGF$\beta$ also inhibits the inflammatory process of $\mathrm{T}$ helper-2 cells, modulates antigens presenting cell (APC) and induces IgA production.High level of CD-14 content in breast milk will play a protective function from allergic development. Lactoferrin helps to accelerate gastrointestinal maturation that can prevent allergies. Secretory IgA in breast milk also helps the intestine from allergic events by coating the intestinal barrier mucosa to prevent the occurrence of allergen sensitization (Friedman et al., 2005; Adkinson, 2008). Ehlayel et al., (2008) states that children who did not receive exclusive breastfeeding has a prevalence of allergic rhinitis $12.4 \%$ higher than children who consumed exclusive breastfeeding. 
Table.1 Subject characteristics

\begin{tabular}{lccccc}
\hline \multirow{2}{*}{ Variable } & \multicolumn{2}{c}{$\begin{array}{c}\text { Intermittent } \\
\text { allergic }\end{array}$} & \multicolumn{2}{c}{$\begin{array}{c}\text { Persistent allergic } \\
\text { rhinitis }\end{array}$} & Total \\
\cline { 2 - 6 } & $\mathbf{n}$ & $\mathbf{\%}$ & $\mathbf{n}$ & $\mathbf{\%}$ & $\mathbf{n}(\%)$ \\
\hline Gender & 15 & 65.2 & 8 & 34.8 & $23(51.1)$ \\
Male & 14 & 63.6 & 8 & 36.4 & $22(48.9)$ \\
Female & & & & & \\
Age & 20 & 69 & 9 & 31 & $29(64.4)$ \\
Child (5 to 11 years) & 8 & 57.1 & 6 & 42.9 & $14(31.2)$ \\
Early adolescent (12 to 16 years) & 1 & 50 & 1 & 50 & $2(4.4)$ \\
Teenager (17 to 18 years) & & & & & \\
Interrupted activity & 2 & 40 & 3 & 60 & $5(11.1)$ \\
Not interrupted & 26 & 81.2 & 6 & 18.3 & $32(71.1)$ \\
Slightly interrupted & 1 & 12.5 & 7 & 87.5 & $8(17.8)$ \\
Very interrupted & & & & & \\
Allergy Risk & 23 & 71.9 & 9 & 28.1 & $32(71.1)$ \\
Low-moderate & 6 & 46.2 & 7 & 53.8 & $13(28.9)$ \\
High & & & & & \\
\hline
\end{tabular}

Table.2 Bivariate analyzed between allergic rhinitis and breast feeding

\begin{tabular}{|c|c|c|c|c|c|}
\hline \multirow[b]{2}{*}{ Variable } & \multicolumn{2}{|c|}{ Allergic rhinitis } & \multirow[b]{2}{*}{$\boldsymbol{P}$} & \multirow[b]{2}{*}{ OR } & \multirow[b]{2}{*}{$95 \% \mathrm{CI}$} \\
\hline & $\begin{array}{c}\text { Intermittent: } \\
\mathbf{n}(\%)\end{array}$ & $\begin{array}{c}\text { Persistent: } \mathbf{n} \\
(\%)\end{array}$ & & & \\
\hline Feeding history & & & & & \\
\hline Exclusive breastfeeding & $22(81.5)$ & $5(18.5)$ & 0.005 & 6.9 & $1.78-26.85$ \\
\hline Non exclusive breastfeeding & $7(38.9)$ & $11(61.1)$ & & & \\
\hline
\end{tabular}

Fig.1 Comparison of intermittent and persistent allergic rhinitis

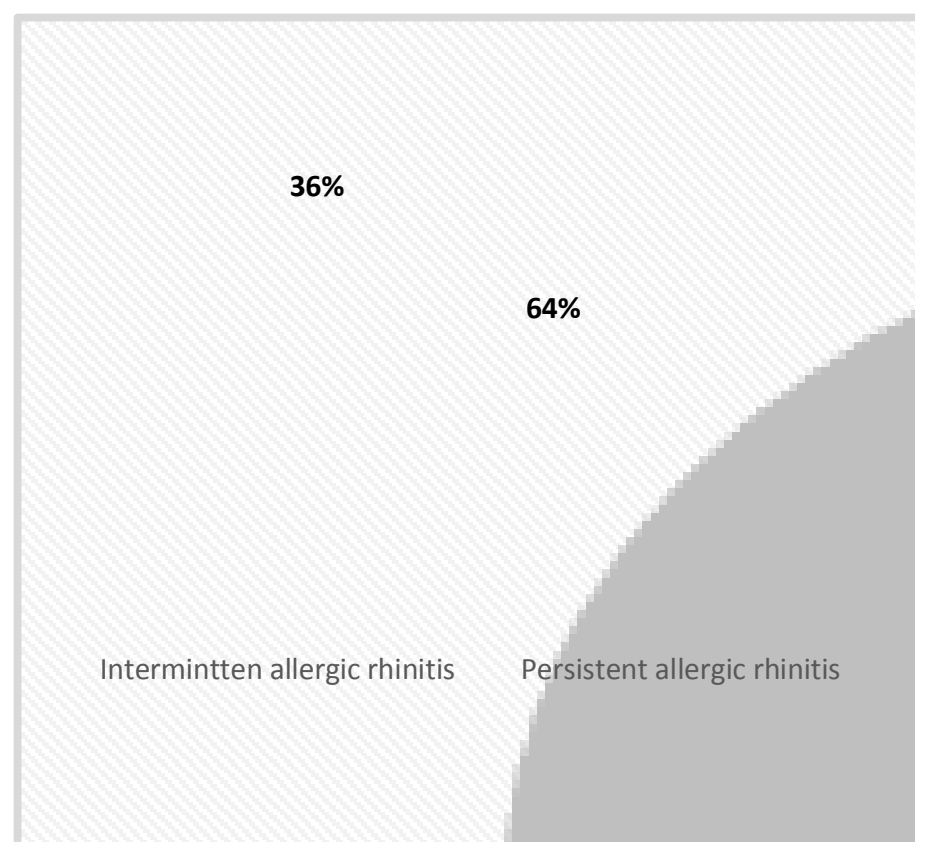


Fig.2 Comparison of exclusive and non exclusive breast feeding

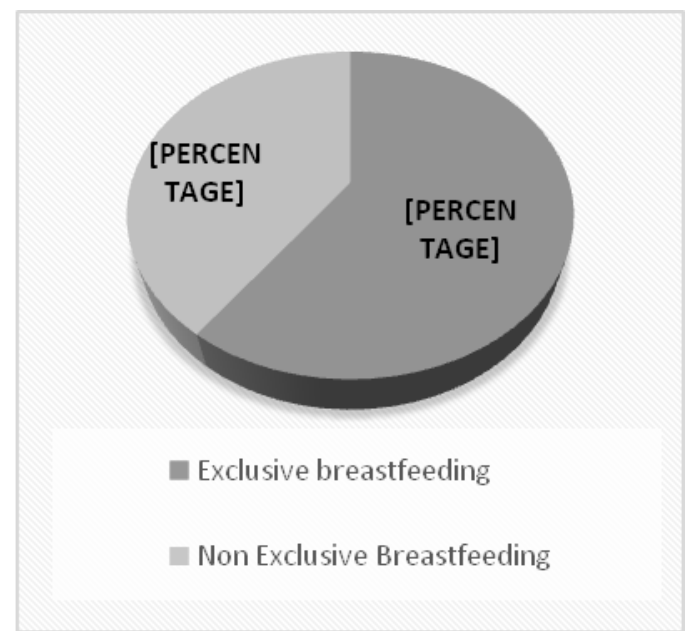

Similar in our results, allergic rhinitis and feeding history in infancy shown a statistically significant difference where children who consumed non exclusive breast feeding will have 6.9 times higher to suffer persistent allergic rhinitis $(P=0.005 ; 95 \%$ CI $1.78-26.85)$.

Allergic rhinitis does not cause the death but can affect the quality of life because of sleep disturbance, decreased concentration and work productivity, decreased performance in school and social activities and even psychological disorders such as depression if allergicsymptom becomeworsening (Rotiroti and Scadding, 2016; Wuryanti and Wibowo, 2015).

Allergic rhinitis in fact disturbs the patient in performing daily activities. About $81 \%$ of subjects suffering from intermittent allergic rhinitis experienced slightly interrupted in performing daily activities, while $87 \%$ of patients who had persistent allergic rhinitis experienced severe interrupted inperforming daily activities.

This is in accordance with study conducted by Eli O. Meltzer (2016) which states that allergic rhinitis can affect the quality of life in a person including physical and socialdaily activities, sleep disturbances, fatigue, irritability, depression, attention deficit, memory and learningdisturbance.

Allergy symptoms are also related to genetics. This symptoms were found in $39.8 \%$ of children if their mother has a history of allergy and $30.2 \%$ if their father has the symptoms of allergy (Johansson et al., 2004). We divide allergic risk factors into low-moderate and high risk of allergy based on family history. $72 \%$ of allergic rhinitis children were included into low-moderate group.
In conclusion, Allergic rhinitis does not cause the death but can affect the quality of life especially make the sufferer experienced sleep disturbances, fatigue, irritability, depression, attention deficit, memory and learning disturbances. Allergic rhinitis and feeding history in infancy showed a relation where children who consumed non exclusive breastfeeding will have 6.9 times higher to suffer persistent allergic rhinitis. It is highly recommended to be given exclusive breastfeeding during infancyasa preventive factors against allergic rhinitis.

\section{References}

Adkinson NF. Middleton's Allergy: Principles and Practice 7th Edition. 7th ed. Philadelphia: Mosby Elsevier; 2008.

Broek JL, Bousquet J, Baena-Cagnani CE, Bonini S, Canonica GW, Casale TB, et al., Allergic Rhinitis and its Impact on Asthma (ARIA) guidelines: 2010 Revision. J Allergy Clin Immunol. 2010;126(3): 466-76.

Ehlayel MS, Bener A. Duration of breast-feeding and the risk of childhood allergic disease in a developing country. Allergy Asthma Proceed 2008; 29: 386-91.

Friedman NJ, Zeiger RS, Diego S. The Role of Breastfeeding in the Development of Allergies and Asthma. J Allergy Clin Immunol 2005;115(6): 1238-48.

Ji Y, Liu Y, Yang N. Pediatric Rhinitis Risk Factors. Exp Ther Med 2016;12(4):2383-6.

Johansson SG, Bieber T, Dahl R, Friedmann PS, Lanier $\mathrm{BQ}$, Lockey RC, et al., Revised nomenclature for allergy for global use: report of the nomenclature review comittee of the world allergy organization. $\mathbf{J}$ 
Allergy Clin Immunol 2004;11:38-83.

Li Y, Jiang Y, Li S, Shen X, Liu J, Jiang F. Pre-and Postnatal Risk Factors in Relation to Allergic Rhinitis in School-Aged Children in China. PLoS ONE 2015; 10(2): 1-11.

Meltzer EO. Allergic Rhinitis Burden of illness, Qualify of life Comorbidities and Control. Immunol Allergy Clin NAm 2016; 36: 235-48.

Mims JW. Allergic Rhinitis. Facial Plast Surg Clin North Am 2012; 20(1): 11-20.

Rotiroti G, Scadding GK. Allergic Rhinitis-an Overview of a Common Disease. Paediatr Child Health 2016; 26(7): 298-303.

How to cite this article:

Mulya Safri, Muhammad Dipi Abdillah, Aulia Rahman Putra, Benny Kurnia and Muhsin. 2018. Comparison of Exclusive and Non Exclusive Breast Feeding with the Incidence of Allergic Rhinitis in Children. Int.J.Curr.Res.Aca.Rev. 6(4), 15-19. doi: https://doi.org/10.20546/ijcrar.2018.604.003 